\title{
A NEW SPECIES FROM ETHIOPIA AND AN INTERESTING DISJUNCTION IN TYLOPHORA ( ASCLEPIADACEAE)
}

\author{
U. MEVE* \& S. LIEDE†
}

\begin{abstract}
A new species of Tylophora, T. corollae Bullock ex Meve \& Liede (Asclepiadaceae), is described from Ethiopia. This delicate twiner is characterized by yellow, shield-shaped corona lobes with apical appendages.

The non-twining shrub up to $1 \mathrm{~m}$ high, T. fleckii (Schltr.) N.E. Br., so far known to be endemic to Namibia, is for the first time recorded from NE Africa. The interesting biogeographical implications resulting from the extraordinary gap of $4500 \mathrm{~km}$ in its distribution are discussed.
\end{abstract}

Kelwords. Asclepiadaceae, Ethiopia, Namibia, Somalia, Tylophora corollae, Tylophora Heckii.

\section{INTRODUCTION}

In the context of the preparation of accounts for the Flora of Ethiopia and the Flora of Somalia by one of the authors (SL), the material of Tylophora housed in BM, $\mathrm{EA}, \mathrm{FT}, \mathrm{K}$, and $\mathbf{P}$ was investigated.

Only sparse material originating from this region is available, consisting mainly of the widely distributed African elements $T$. heterophylla A. Rich., T. oblonga N.E. $\mathrm{Br}$. and $T$. sylvatica Decne. However, one specimen each of two species so far unknown in the area were found among the material housed in $\mathrm{K}$, raising the number of Tylophora taxa for the combined range of both Floras to five species.

\section{TAXONOMY}

Tylophora corollae Bullock ex Meve \& Liede, sp. nov. Fig. 1.

$T$. corollae Bullock (in sched., $\mathrm{K}$ ).

Type: Ethiopia, Begemder Prov., $82 \mathrm{~km} \mathrm{~S}$ Gondar, along the road to Bahar Dar, c. $12^{\circ} 05^{\prime} \mathrm{N} 37^{\circ} 40^{\prime} \mathrm{E}$, alt. c. $2250 \mathrm{~m}, 16$ ix 1970, De Wilde 7170 (holo. WAG; iso. BR, K).

Corolla flavo-viridis, rotata, puberulus; corona flava, rectangulari-scutata, appendicibus linearibus obtusis erectis; pollinia ovoidea-pyriformia, suberecta; connectivum appendicibus late obovatis.

Plants delicate twiners up to $1.5 \mathrm{~m}$ high; stems $1-2 \mathrm{~mm}$ diam., green, puberulous with appressed trichomes, sparsely branched; latex colour unknown; leaves 2.5-6× $1.5-3 \mathrm{~cm}$. ovate, basally cuneate, apically acuminate, membranous, glabrous on both surfaces or nearly so, though puberulous along the main ribs, petiole $0.3-1 \mathrm{~mm}$ long,

* Institut für Botanik, Westf.-Wilhelms-Universität, Schlossgarten 3, D-48149 Münster, Germany.

$\div$ Spezielle Botanik, Biologie V. Universität Ulm, Albert-Einstein-Allee 11, D-89069 Ulm, Germany. 


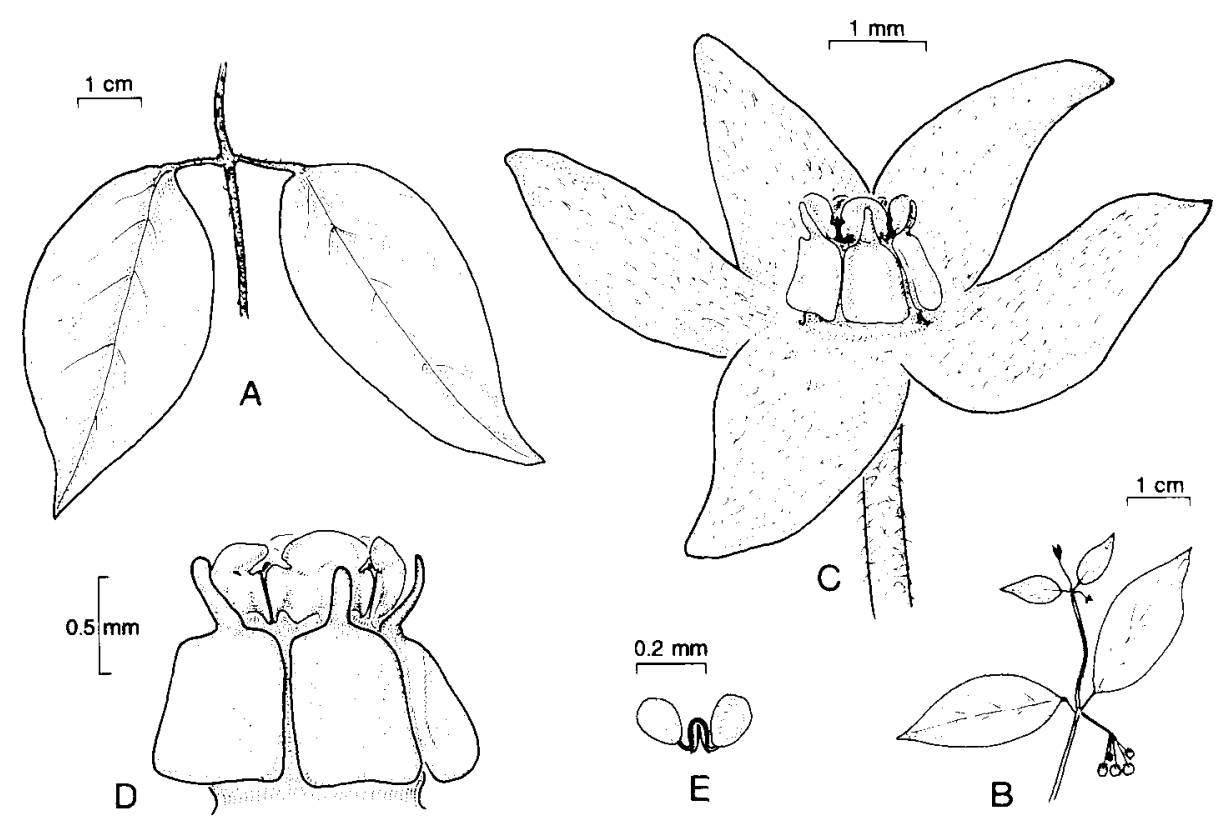

FIG. 1. Tylophora corollae Bullock ex Meve \& Liede. A, node with pair of leaves; B, young shoot with budding inflorescences; $\mathrm{C}$, flower; $\mathrm{D}$, gynostegium and corona; $\mathrm{E}$, pollinarium (drawn by U. Meve from De Wilde 7170).

densely puberulous on upper surface; inflorescences extra-axillary at upper nodes, 5(-7)-flowered, sciadioidal, peduncles 6-8mm long, horizontally spreading, glabrous or nearly so; bracts lanceolate, acute, up to $0.5 \mathrm{~mm}$ long, abaxially pilose, adaxially glabrous; pedicels $8-12 \mathrm{~mm}$ long, glabrous; sepals $0.4-0.5 \mathrm{~mm}$ long, lanceolate, acute, brownish red, abaxially pilose, adaxially glabrous; buds subglobose-ovoid, with contorted aestivation; corolla rotate, lobes basally fused, c. $3 \times 1.8 \mathrm{~mm}$, ovate, membranous, patent, apex slightly twisted, bases overlapping, adaxially greenish cream, puberulous, abaxially greenish, glabrous; gynostegial corona consisting of 5 separate lobes $(\mathrm{Cs})$ adnate to staminal column below anthers, c. $1.1 \times 0.6 \mathrm{~mm}$ in total, solid, massive, quadrangular in the basal $3 / 4$, the upper $1 / 4$ suddenly constricted to a linear obtuse appendage, yellowish; gynostegium c. $0.5 \times 1 \mathrm{~mm}$, atop a very short stipe, c. $0.1 \times 1 \mathrm{~mm}$; anther wings obliquely bent inward, c. $250 \mu \mathrm{m}$ long, parallel to each other; anther appendages $c .0 .4 \times 0.1 \mathrm{~mm}$, very broadly ovate, appressed to the stylar head; pollinaria: corpusculum ovate, c. $0.1 \mathrm{~mm}$ long, caudicles thin, terete, slightly upwardly bent, pollinia suberect, apically attached to the caudicles, c. $0.15 \times 0.1 \mathrm{~mm}$, ovoid-pyriform; stylar head flattened, slightly convex; follicles fusiform when young, glabrous; seeds not seen.

Distribution. Ethiopia. Fig. 2.

Habitat. c. $2250 \mathrm{~m}$ a.s.l.; twining in shrubs on a rather steep rocky slope. Slope additionally covered by small trees and alternating with open patches covered by herbs. 


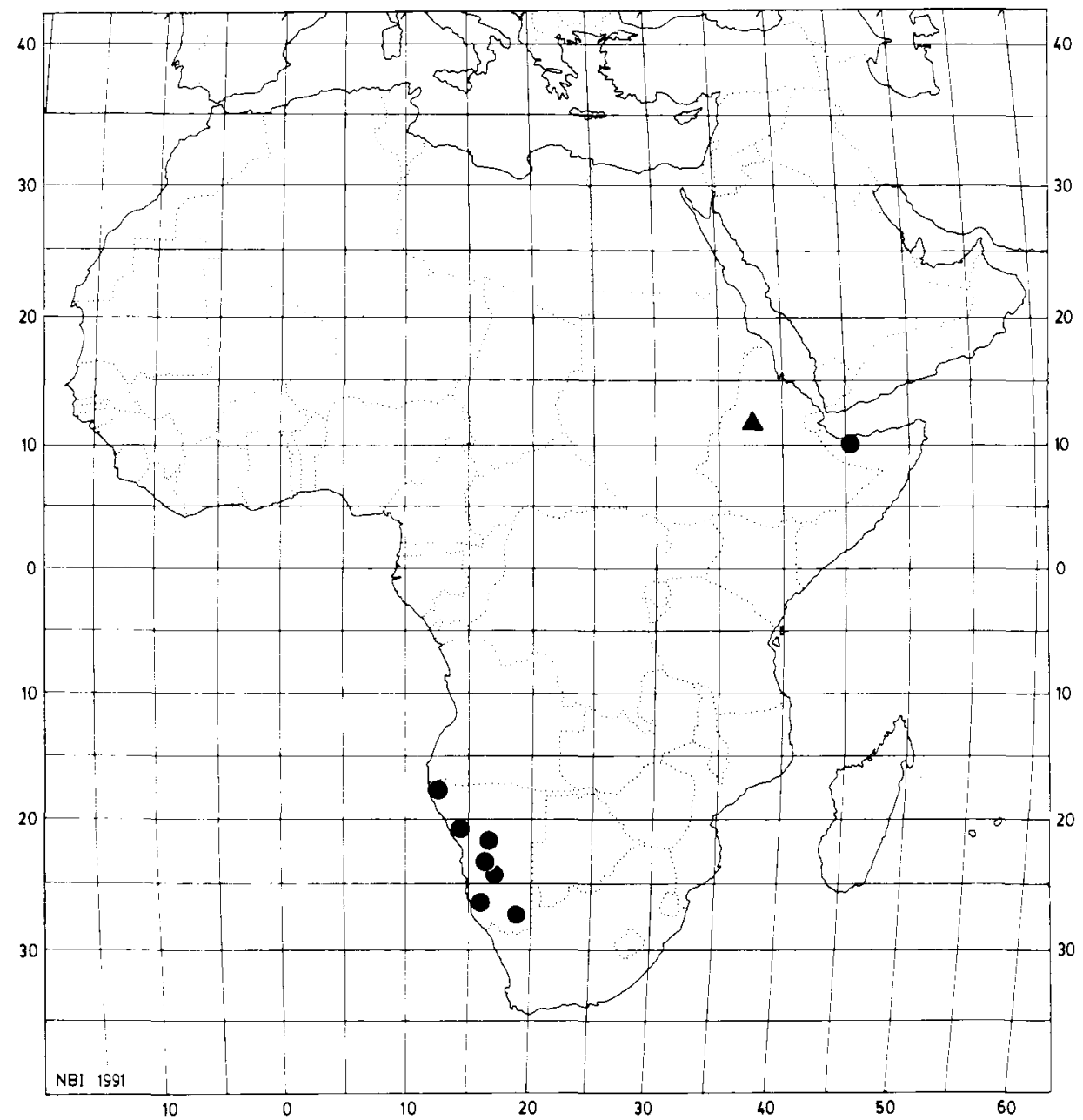

FIG. 2. Distribution of $T$. corollae (triangle) and T. fleckii (dots); data from herbarium specimens, from Bruyns (1990) and Huber (1967).

Flowering time. September.

Conservation status. Rare, known only from the type collection.

Tylophora fleckii (Schltr.) N.E. Br., Fl. Cap. 4(2): 766 (1908); H. Huber, in Merxm., Prodr. Fl. S.W.Afr. 114: 70 (1967); Bruyns, Cimbebasia 12: 164 (1990). Fig. 3.

Basionym: Tylophoropsis fleckii Schltr., Bull. Herb. Boiss. 7: 39 (1899).

Type: Gamsberg, Fleck 431 (type not traced).

Plants erect to straggling shrublets, occasionally slightly prostrate, $20-50(-100) \mathrm{cm}$ high: stems $2-7 \mathrm{~mm}$ broad, rigid, brownish, finely puberulous with appressed trichomes (at least when young), basally woody, freely branching, latex clear; leaves 


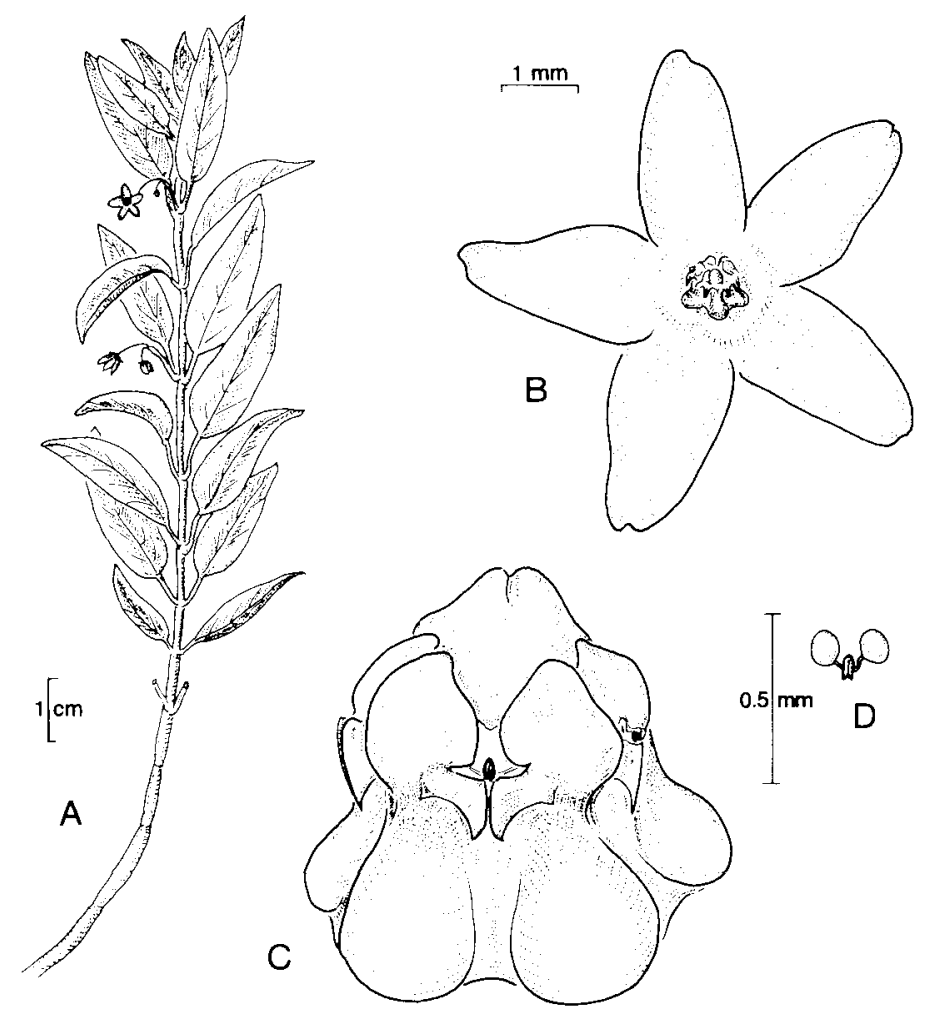

FIG. 3. Tylophora fleckii (Schltr.) N.E. Br. A, flowering shoot; B, flower; C, gynostegium and corona; D, pollinarium (drawn by U. Meve from $\operatorname{Wood} \mathrm{S} / 73 / 135$ ).

lanceolate to ovate, $1-3 \times 4-10 \mathrm{~mm}$, basally cuneate, apically acute, puberulous on both surfaces, more densely so along the veins, petiole $2-6 \mathrm{~mm}$ long, puberulous: inflorescences extra-axillary at upper nodes, suberect to horizontally spreading, with short peduncle, 3-6mm long, puberulous, 1-3(-5)-flowered, accompanied by several bracts, oblong, obtuse, $1-2 \times 0.5 \mathrm{~mm}$, abaxially pilose, adaxially glabrous; pedicels 3-6mm long, puberulous, slightly curved downward; sepals lanceolate-oblong. obtuse to acute, $1.5-2.5 \mathrm{~mm}$ long, fused at the base, green, abaxially puberulous, adaxially glabrous; buds subglobose, with contorted aestivation; corolla rotate, $5-10 \mathrm{~mm}$ in diam., glabrous, adaxially white, yellowish to (pink-)brown, abaxially greenish; corolla fused for $1 / 4$ to $1 / 3$, tube usually raised to a very slight annulus directly surrounding the base of the corona, corolla lobes oblong-ovate, $2-3 \times$ c. $2 \mathrm{~mm}$. membranous, apex truncate-emarginate, often recurved and slightly twisted, bases overlapping; gynostegial corona sessile and basally fused with the corolla tube, consisting of 5 separate staminal lobes (Cs) adnate to staminal column below anthers, $0.3-0.4 \mathrm{~mm}$ long, globosely swollen towards the base to $0.3-0.5 \mathrm{~mm}$ in diam., tapering strongly towards the base of the anther, yellowish; gynostegium c.1.5 $\times 1 \mathrm{~mm}$, anther wings vertical, protruding, c. $180 \mu \mathrm{m}$ long, widely spreading toward the guide rail 
mouth; anther appendages subreniform, incurved towards the base of the stylar head; pollinaria: corpusculum ovate, c. $60 \mu \mathrm{m}$ long, caudicles thin, terete, horizontal to suberect, pollinia subapically attached to the caudicles, subglobose, c. $100 \times 80 \mu \mathrm{m}$; stylar head conical, $0.5-0.75 \times 0.7-1 \mathrm{~mm}$, apex slightly bifurcate; follicles ovoid-fusiform, acute, $4-6 \mathrm{~cm}$ long, up to $1 \mathrm{~cm}$ broad in the proximal third, glabrous.

Distribution. Namibia, Somalia. Fig. 2.

Habitat. $1500-2350 \mathrm{~m}$ a.s.l.; in sand along a water course (Somalia: Wood, in sched.); usually in boulder fields or among rocks on steep to gentle slopes high up on mountains (Namibia: Bruyns, pers. comm.).

Flowering time. December--July.

Conservation status. Collected once only in Somalia, but sporadically frequent in Namibia (Bruyns, pers. comm.) and therefore not threatened as a species.

Specimens examined. SOMALIA. Suq Sadey near Sheikh, on the bank of a small sandy water course, 4500ft, Wood S/73/135 (EA, K).

NAMIBIA. Kaokoveld, rocky hillock at Ombepera, $17^{\circ} 35^{\prime} \mathrm{S} 12^{\circ} 52^{\prime} \mathrm{E}$, Winter \& Leistner 5417 (EA); Lüderitz, Farm Garub near Aus, 4 iv 1968, Giess 10308 (M); Kraikluft (=Pieterskloof), Karasberg, 23 xii 1912, Pearson 8207 (BM).

\section{DISCUSSION}

The variability of coronal morphology encountered in Tylophora is rather low, especially among the African representatives. Normally simple staminal corona lobes develop from the staminal column at the base of the anthers (cf. T. fleckii, Fig. 3). Very often, the corona lobes widen or elongate at their bases to form a pentagonal outline of the pollination apparatus (e.g. T. fleckii, T. sylvatica). In T. corollae a new character is added to the range of coronal structures in the genus. Here, the shield-shaped, rectangular corona lobules are tipped by appendages which support the backs of the anthers and equal them in length. The resulting impression is that of a little crown, to which the specific epithet chosen by A. Bullock (in sched.) obviously refers.

Among African taxa, the formation of additional corona appendages has so far been described only for Tylophora erubescens (Liede \& Meve) Liede (Liede \& Meve, 1994; Liede, 1996). There, however, the appendages are reflexed and originate from the abaxial regions of the corona. The same construction is found in the non-African T. indica (Burm.f.) Merrill, which ranges from the Seychelles in the west via the Indian subcontinent as far east as the Malayan region. The much elongated, erect corona appendages typical for $T$. indica again emerge from the back of the coronal lobules. The habit of $T$. indica, its indumentum, the shape and colour of the corolla and the often shortly stipitate gynostegium are very similar to what is found in 
T. corollae. However, differences occur in the shape of the corona lobes as well as in the guide rails and the orientation of the pollinia (erect in $T$. corollae, pendulous in $T$. indica), thus supporting the independent status of $T$. corollae. Indeed, $T$. indica closely resembles $T$. erubescens from Malawi and Tanzania judged by gynostegial and coronal characters.

T. fleckii has been recorded from various localities in Namibia (Fig. 2; Bruyns, 1990). This first record from Somalia indicates a considerable disjunction in its distribution area. From the morphological point of view, the only difference between the Namibian representatives and the Somalian ones is in the annulus, which, though gentle, is clearly observable in Namibian flowers, but reduced to a very slight elevation of the corolla in Somalian ones. However, this difference is of a very minor nature and does not require formal recognition, especially in the light of the considerable variability in annulus formation in other asclepiad species (e.g. Orbea verrucosa (Masson) L.C. Leach; Leach, 1978).

The specimen of the Somali collection is without fruits. Since fruit morphology is a very conservative character in Asclepiadaceae, differentiations on this level are not to be expected.

The gap between the two partial distribution areas spans at least $4500 \mathrm{~km}$. Species whose distribution areas extend more or less uninterruptedly from SW to NE Africa are not especially rare (e.g. compare Verdcourt, 1969; Thulin, 1994). Verdcourt therefore argues for the existence of an 'arid corridor' between the south-western and north-eastern parts of the continent at least since the Miocene. Uninterrupted arid conditions should have prevailed since then, before the pluvial periods of the Pleistocene gave rise to profound shifts in the vegetation cover of Africa (Verdcourt, 1969; Van Zinderen Bakker, 1976). However, while parts of the Sahara were not arid, in SW Africa and Somalia even the wettest periods did not result in non-arid conditions (Verdcourt, 1969). These areas therefore constituted refuges for semidesert plant life before a somewhat shifted and reduced 'arid corridor' recently arose across the continent more or less without interruption. Other hypotheses, such as 'long-distance dispersal', seem to be rather unlikely considering the enormous size of the gap found in T. fleckii. Marked NE-SW disjunctions are quite rare at species level (cf. Thulin, 1994), and also in Asclepiadaceae this is the only one known so far. Mostly, vicarious species pairs or independent species of single genera have evolved in these distant areas. The disjunctions in African Asclepiadaceae primarily involve genera exhibiting NE-SE (e.g. Orbea, Leach, 1978) or NW-SE disjunctions (e.g. Brachystelma, Meve \& Porembski, 1993; Neoschumannia, Meve, 1995).

The morphological conformity and stability shown by collections of $T$. fleckii from both partial areas and the enormous size of the gap between them indicate, in our opinion, a very high age for this species.

The erect growth form exhibited by $T$. fleckii is a rare feature within African Tylophora, shared only by $T$. congolana from West and Central Africa and $T$. coddii Bullock (1964) from the Transvaal, South Africa. T. congolana usually grows on seasonally wet and muddy grasslands or even in swamps, whereas $T$. coddii is reported from rocky stands comparable to those where $T$. fleckii is found. 


\section{ACKNOWLEDGEMENTS}

Dipl.-Biol. P. Deitelhoff is thanked for linguistic improvement of the Latin diagnosis.

\section{REFERENCES}

BRUYNS, P. V. (1990). New plant records from the Brandberg. Cimbebasia 12: $161-166$.

BULLOCK, A. A. (1964). Tylophora coddii. Flow: Pl. Afr. 36: t. 1435.

HUBER. H. (1967). Asclepiadaceae. In: MERXMÜLLER, H. (ed.) Prodromus einer Flora von Südwestafrika, 114: 1-71. Lehre: Cramer.

LEACH, L. C. (1978). A contribution towards a new classification of Stapelieae (Asclepiadaceae) with a preliminary review of Orbea Haw. and descriptions of three new genera. Excelsa Tax. Ser. 1: 1-75.

LIEDE, S. (1996). Cynanchum - Rhodostegiella - Vincetoxicum - Tylophora: New considerations on an old problem. Taxon 45: 193-211.

LIEDE, S. \& MEVE, U. (1994). A new species of Tylophoropsis (Asclepiadaceae) and notes on the genus. Kelv Bull. 49(4): 749-756.

MEVE. U. (1995). Neoschumannia (including Swynnertonia), a primitive genus of the Asclepiadaceae-Stapelieae. Pl. Sist. Evol. 197: 233-242.

MEVE, U. \& POREMBSKI, S. (1993). Brachystelma Sims in West Tropical Africa. Bot. Jalmb. Sist. 115: 315-324.

THULIN, M. (1994). Aspects of disjunct distributions and endemism in the arid parts of the Horn of Africa, particularly Somalia. In: SEYANI, J. H. \& CHIKUNI, A. C. (eds) Proc. XIIth Plenary Meeting AETFAT, Malawi, 2: 1105-1118.

VAN ZINDEREN BAKKER. E. M. (ed.) (1976). Palaeoecology of Africa, the surrounding islands and Antarctica. Cape Town: Balkema.

VERDCOURT, B. (1969). The arid corridor between the north-east and south-west areas of Africa. Palaeoecol. Afr. 4: 140-144. 